\title{
ART(E/I)KULAZIOA: IRAGAN-ORAINALDIKO NARRATIBA AKTIBOEN ERAIKUNTZA, PRAXI ARTISTIKOAREN DISZIPLINARTEKOTASUNETIK ABIATUTA ${ }^{1}$
}

\section{Onintza Etxebeste Liras}

Universidad del País Vasco/Euskal Herriko Unibertsitatea. Ikerketa Arte Garaikidean Doktorego

Programa/lkerketa Arte Garaikidean Doktorego Programa

\section{Laburpena}

Testu honek arte esparruak, metodologia aktibo eta transbersal anitzetatik abiatuta, ondarearen iraunkortasun, eraiketa eta berreraiketa prozesuan eman ditzazketen aukeretan erreparatzen du, ikusmira eta narratiba sensible desberdinen bila. Patrimonializaziotik artikulaziorako aldaketa proposatzen da iraganera gerturatzeko prozeduratzat, agente bizi eta multipleak harreman sare hedatu baten sakoneran antzemanez. Iragan-orainaldiko artikulazioa, instalazio izaera eta haren performatibitatea goraipatzen dira, metodologia artistikotik abiatuta, kultur identitatearen eraikuntza-prozesu aktiboaren eta bere ondarearen "iraunkortasunerako" zein ezagutzarako baliabide moduan.

Hitz gakoak: ARTIKULAZIOA; ARTEA; IRAGANA; ARKEOLOGIA GARAIKIDEA; SAREA

\section{ART(I)CULATION: THE CONSTRUCTION OF ACTIVE PAST-PRESENT NARRATIVES FROM THE ARTISTIC PRACTICE AND ITS INTERDISCIPLINARITY}

\section{Abstract}

This text, based on different active and transversal methodologies, focuses on the possibilities the artistic field offers to the constitutive process of the heritage, by construction and reconstruction, and looking for alternative sensitive and viable narrative perspectives. For this purpose, it is proposed a modification of the concept from patrimonialization to articulation as a way to approach the past, considering this as a network of multiple and active relationships. The past-present articulation, the nature of the installation and its performativity are appreciated, from the artistic methodology, as a resource for the "active" and social construction of heritage, cultural identity, and its contemporary "sustainability".

\section{Keywords:ARTICULATION; ART; PAST; CONTEMPORARY ARCHEOLOGY; NETWORK}

\footnotetext{
Etxebeste Liras, Onintza. "ART(e/i)KULAZIOA: Iragan-orainaldiko narratiba aktiboen eraikuntza, praxi artistikoaren disziplinartekotasunetik abiatuta". AusArt 6 (1): 55-71. DOI: 10.1387/ausart.19391
}

\section{AUSART}




\section{SARRERA. IRAGANAREN LANTZE PROZESUEKIN TALKAN}

Ondarea iraunkor egitearen beharra galera sentimenduari lotuta egon ohi da, iragan batekiko gerturapena, eta ezagutza, desagertzear dagoenean sortu izan delarik hura 'bizirik'mantentzeko nahia. Oroimenaren 'bizirik' mantentze hori, hain zuzen, bat egingo luke berreskuratzea ezinezkoa den iraganarekiko nostalgiarekin, baita arazo garaikideen aurrean behinolako garai hobe baten ideiarekin ere, honakoa erreferente idealtzat hartuta iraungarri egiteko gogoarekin (Lowenthal 1985).

Idei hauek harreman estua dute historiaren mantenu, eraikuntza edo berreraikuntzarekin, baita bere patrimonializazio prozesuarekin ere. Hala nola, gaur egun iraganaren, kulturaren eta identitatearen nolabaiteko gordailu instituzionalak bihurtu dira museoak, haien ardurapean dagoelarik iragan eta orainaldiaren arteko patrimonializazio prozeduren gauzatzea, baita honakoekin erlazionaturiko ezagutza gizarte mailan helaraztea ere. Museoek ireki izan dituzte, hain zuzen, lehenaldira begiratzen dituzten lehioak, egungo kontestutik iragandakora zabalduz geure begirada, denbora geruza desberdinak batuz, eta, aldi baterako bada ere, egonkor eginez.

Iraganeko ezagutza eta transmisio zainketaren inguruko sentsibilitatea historikoki, etnologikoki edota folkorikoki landu den heinean, hala ere, honakoaren errepresentazio eta mantenurako eman diren pausoak geroz eta estandarizatuagoak direla antzematen da, iragan eta orainaldiaren arteko tartea geroz eta gehiago handituz. Orokorrean betiere, instituzio hauen proposamenak ondarearen eredu objektualetik abiatzen direla esan daiteke, honakoak iraganean soilik finkatuz, euren ezagutza igortzeko erabiltzen dituzten bideak geroz eta mardulagoak direlarik gaur egun bizi dugun testuinguru postmodernoaren mugikortasunean (Arrieta 2012, 71).

Museifikazio tradizionalaren baitan, beraz, ondare materiala ez-materiala baino goraipatuagoa izan da orokorrean. Honela, iraganaren modeloa aurretik prestatutako eszenatoki moduan irudikatu ohi izan da, zerratutako eremu batean finkatuz harekin erlazionaturiko idei oro. Landutako eraiketa prozesua, beraz, historikoki zein sozialki onartutako adierazle multzoen errepikapen 'mimetiko' eta gehienetan 'fisikoaz' baliatzen dela esan daiteke, aldaketarik gabeko birsortze baten moduan. XIX. mendetik datorkigun museifikazio eredua, krisialdian bailitzan, erronka ederrarekin topatzen ari da iragana iraunkorra egiteko prozesu garaikideen bila. 

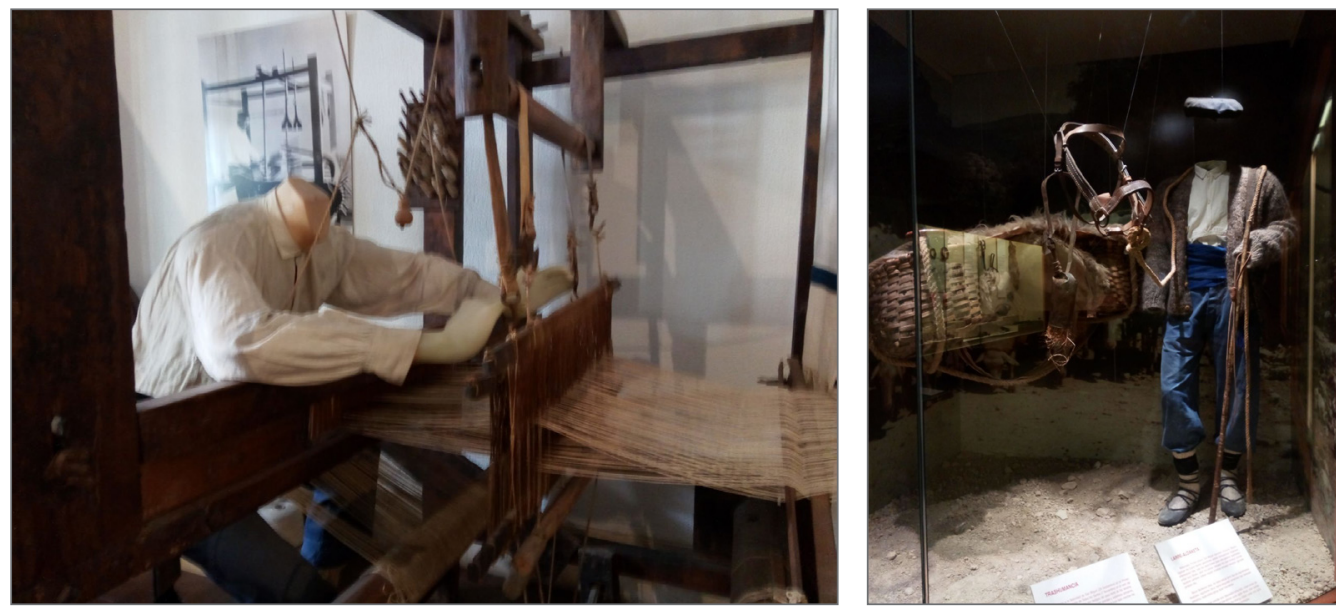

Bilboko Euskal Museoan ateratako erakusketa iraunkorraren bi adibide (2017)

Patrimonializazio eredu mota honen ondorio bihurtzen ari da, hain zuzen, iraganarekiko ezagutza alegiazkotasunean finkatua izatea, kutxa beltzaren atenporaltasun estatikora mugatuz haren transmisioa; objektu iraunkorrak, ohiko erakusketa formatuak, narratiba historiko-antropologikoaren didaktika lineala, kontsumo turistikoaren indarra... gizarteak bere iraganarekin eta hartatik eratortzen den identitate kulturalarekiko duen harreman eta esperientzia guztiz baldintzatzen duten patroietan jaustea eraginez. Estatizismoari men eginez, esan bezela, lehenaldikoarekiko ezagutza esentzialismo jakinetara mugatzen dituzte prozedura hauek, hartara gerturatzeko eta bere inguruan kontakizunak eraikitzeko modu garaikide posibleetan erreparatu gabe.

\section{DIAKRONIEN BAITAN. ONDAREA EZ DA EGONKORRA}

Aurreko planteamenduaren arazoari kontrajarrita, jakina da inoiz baino informazio gehiago dagoela denon eskura, sarean ditugun aukerak amaigabeak direla edozein testuingururen testigantza emateko, hamaika bide irekitzen ari direlarik ondare eta transmisioaren gestiorako bidean. Bai instituzioen eskutik (museoak, udaletxeak, foru aldundiak), zein harietatik at (elkarteak, blog-ak, sare sozialak, telebistako programak, artxibo pertsonalak), informazioaren zirkulazioak lehen baino askoz ere mugikortasun handiagoa du; mediatikoki, 
eta esparru anitzei dagokionez, ezagutzaren helarazpenaren 'demokratizazio' berri bat ematen ari dela esan daiteke. Oparotasun honek, baina, badu bere kontrako aldea, datozen bezain laister ahazten baititugu etengabeko informazioaren bonbardaketaren bitartez iristen zaizkigun berriak, datuak eta loturak. Eratzen eta kontsumitzen diren azkartasunaren ondorioz, memoriak berezkoa zuen iraunkortasuna murriztuz doa ezinbestean. Todorov-en hitzetan:

"Arrojados a un consumo cada vez más rápido de información. (...); (...), estaríamos condenados a festejar alegremente el olvido y a contentarnos con los vanos placeres del instante. (...), la memoria estaría amenazada, ya no por la supresión de información sino por su superabundancia. (...), en vez de fortalecerse nuestra resistencia, seríamos meros agentes que contribuyen a acrecentar el olvido"

(Todorov 2000, 14)

Gehiegizko informazioa eta haren hedatze azkarrak, beraz, honakoa segmentu bihurtzea zailtzendu, iragan urrun eta batez ere gertutik datozkigun testigantzak orainaldian disolbatu besterik egiten ez direlarik. Horrez gain, informazio guzti honen 'fidegarritasuna' batzuetan zail egiten da frogatzen, desinformazioa ere sortuz bere baitan. Mugikortasunaren eredu globalizatuak, horrenbestez, buruz buru egiten du lehen aipatutako prozesu instituzionalekin; bigarren hauek, identitatea eta kultura iraunkor egiteko erabiltzen dituen ohiko patrimonializazio prozesuen ondorioz, iragana errepresentazio sinboliko zurrunetan hesitzen dituzte. Lehenengoarekin, ordea, ondarea eta iraganarekiko harremana superfizialki hedatu eta modu iragankorrean sakabanatu egiten da askotan.

Arazoaren parte den iruditegi estatikoen eredutik abiatuta, eta aurkari diren bi prozesu hauen baitan, hain zuzen, Edward Said-ek 'esenzialismo sinkroniko' kontzeptuaren ekarpena interes handikoa da gaiaren inguruko ikusmira berrien hausnarketan. Haren hitzetan, ikuspegi ororen indarra honakoa aurrera eramaten duten instituzio, giza-talde edo diskurtsoen baitakoa da, beraz, interesekotzat jotzen diren edo/eta onartutako kontzeptu babestuen baitan transmititzen dira iraganetik eratorritako idei, uste, irudi eta lotura estatiko horiek, lehen planteatutako 'esenzialismo sinkroniko'-a dena eratuz. Era berean, esentzialismo horri aurre egiten dien indarrak ere existitzen direla gehitzen du, edozein xehetasunean eragitekotan sistema osoaren zentzua eraldatu ditzazketenak. Eragin hauek, eta euren presioaren ondoriozko detaileen eraldaketak, beraz, egonkortasunarekin apurtzeko aukera emango luke 
diakronia bat sortuz, eta, hortaz, honakora gerturatu eta hura ezagutzeko dugun moduan eraginez (Said [1997] 2008, 319).

Horrenbestez, Said-en ekarpenaren interesgarritasuna bi puntutan aurki daiteke. Alde batetik, iruditegien interpretazio eta egiazkotasuna boterearen baitakoa dela antzeman dezakegu bere hitzetan, iraganaren eraiketa eta objektibotasuna zalantzan jartzen baitu. Lehenaldiko gertaera eta baloreak 'aldaezinak' izango dira, bederen, egungo gertakari politiko anitz legitimatu eta baliogarri egingo dituztenak. Honekin bat dator, beraz, diskurtso historiko-narratiboaren taxutzean, zanpatzaile eta menderatuen arteko duda-muga goraipatua, iruditegien eraiketa eta ondare historikoaren aukeraketa prozedurekin zerikusi zuzena duelarik. Halaber, argi du Haraway-k zera dionean; "(..) las luchas sobre lo que será considerado como versiones adicionales del mundo son luchas sobre como ver" (Haraway 1991, 333).

Said-en esaldira bueltatuz, bigarren idei nagusia, egonkortasun eta ezegonkortasunaren arteko harremana liminala, fina eta hauskorra izan daitekeela, inguruko eragileen indarraren baitan. Hala nola, Raimond Williams-ek ([1973] 2001) ere desegonkortasun hori defendatzen du zera dionean, kultur identitatearen transmisioa nahigabeko aldaketez horniturik egon beharko duela bizirik badarrai, eta helarazpen hori historiaren, gizartearen eta testuinguruaren etengabeko aldaketa aktibo eta performatiboekin bat egitea ezinbestekoa dela, alegiazko kultura zendu baten transmisioa litzatekeelako bestela. Kulturaren uneoroko eraldaketa egonkorraren inguruan, Baumanek ere egiten du bere hausnarketa:

“(...) la cultura «se perpetúa» en la medida en que se mantiene viable y poderosa, no el modelo, sino la necesidad de modificarlo, de alterarlo y reemplazarlo por otro. Así pues, la paradoja de la cultura se puede reformular como sigue: todo aquello que sirve para la preservación de un modelo socava al mismo tiempo su afianzamiento"

(Bauman 2002, 33).

Azken ekarpena egitearren, diakroniaren desegonkortasunarekin dantzan, Todorov-en ustetan, iraganaren iraunkortasuna orainaldiarekin dituen binkuluen baitan emango da, denboran zehar izandako aldaketa eta testigantza guztietaz eraldatuta, haietaz baldintzaturik, denborak bere gain ipinitako geruza guztien eraginen testigu: "La continuidad expresa la conjunción de la totalidad de las partes del pasado; la diacronía, la permanencia en el pasado del presente, que enriquece a ambos" (Todorov 2000,104). 


\section{BALIABIDE ARTE-AN: EZTABAIDEN BITARTEZKO PERSPEKTIBAK}

Ohiko diskurtso historiko-sozialen eraikuntza beste ikuspuntu honetatik begiratuta, eta lehen aipatutako Said-en planteamenduari jarraiki, beraz, eredu egonkor-esentzialisten eta egungo aldibereko mugikortasunaren artean ematen den talkaren ondorioz desegonkortasun bat emango da ezinbestean. Perspektiba berriak irekiko ditu haustura horrek, eta, zeregin artistikoak, haren parte izateko baliabideak. Esentzialismo sinkronikoa, beraz, indar diakronikoetaz baldintzaturik egongo da ezinbestean:

\begin{tabular}{|c|c|}
\hline ESENTZIALISMO SINKRONIKOA & INDAR DIAKRONIKOA \\
Iraganetik & Orainalditik \\
Patrimonializazioa & Artikulazioa \\
Instituzionala & Soziala \\
Boterea & Demokratizazioa \\
Eredu zentripetoa & Sare hedatua \\
Disziplina itxia & Transdiziplinarra \\
Homogeneoa & Hetereogeneoa \\
Kronologikoa & Multiplizitate espazio-tenporala \\
Mardula & Performatiboa \\
Birsortzea & Berreraikitzea \\
Objektua & Instalazioa \\
& \\
\hline
\end{tabular}

Iraganaren, kultura eta identitatearen egonkortasun-desegonkorraren hausnarketak talka hauek haintzat hartzera garamatza ezinbestean. Hala nola, iraganaren egituraketa, estatikoki zein aktiboki, guk orainalditik eratzen dugun moduan taxutuko da beti, honakoa birsortu, berreraiki, begiratu edo antolatu nahi dugun gisan. Hura iraunarazteko moduaren baitakoa izango da, beraz, haren inguruan izango dugun iruditegi, lotura, harreman eta esperientzia. 
Iraganarekiko lokeran, eta ondorio dituen identitate eta kulturaren eraikuntza haintzat hartuta, arte prozesuarekin bat datorren eredu transbertsalak gai honek bere gain hartzen dituen esparru eta nukleoen arteko erlazionalitateak ahalbidetzen ditu. Halaber, gaur egun pil-pilean daude zeharkako konexio eta harreman kontestual, performatibo eta sensiblekin bat egiten duten proposamen artistikoak, zentzu plastiko zein kontzeptualean esparru desberdinak lantzen dituztenak euren lanetan. Hala nola, proposamen artistikoen bitartez, identitate propio bat eratzeko bidean, harreman diskurtsibo berriak gauzatzen ari dira etengabe, hausnarketa kritikoaren baitan hetereogeneoak diren irudi eta narratiba berriak sortuz (Barcenilla 2017).

Planteatutako arazoari jarraiki, eta, ikusmira berrien bila, iragana elementu ireki eta eztabaidagarritzat lantzea izango litzateke gakoaren hasiera, berezko herentzia-ondare itxi moduan antzeman ordez. Eztabaida horren lekuko planteatzen da, hain zuzen ere, iraganaren, historiaren eta denboraren hausnarketa eta ezagutza aktiboaren eraikuntza, haren inguruan datorkigun iruditegi edota eredu normatibo, kultural eta identitarioa zalantzan jarriko duelarik horrek. Hala nola, iraganaren, identitatearen eta kulturaren izaera etengabe transformatzen ari dela aitortzera garamatza honek, hau da, prozesu aktibo baten moduan, iragan eta orainaldiaren arteko joan-etorrien baitan moldatu, eraiki eta berreraikitzen dela, eta dugula.

\section{ARKEOLOGIA GARAIKIDEAK. PATRIMONIALIZAZIOTIK SARE HEDATUAREN ARTIKULAZIORANTZ}

Patrimonializazioaren eredu mardul edota performatiboaren arteko eztabaidan, izendatzaile desberdin baten beharra dakar bigarren hau etengabeko aldaketez hornituriko prozesu aktibo moduan antzemateak. Hala nola, patrimonializazio hitza baino, artikulazio kontzeptua hobeto datorkigu bat iragan-orainaldiko harreman-lotura diakroniko horien inguruko hausnarketarako, arte esparrutik lantzerako orduan behinik behin. Artikulazioak, hain zuzen, ekintza aktibotzat planteatzen du iraganaren sakontasun multiplea, sare baten mugimenduaren parte bailitzan, kulturaren eta identitatearen konfigurazioa orainaldiko eraiketa eta berreraiketa konstante baten moduan. Iraganaren sakonera sare ireki eta eraldakor bat bezela hartzeak, Rosalind Krauss-en 'hedatuaren' kontzepturekin bat eginez (1979), esparru anitzetik nabigatzeko, perspektiba 
eta ezagutza desberdinetatik gerturatzeko, eta erlazio desberdinak eratzeko aukera emango du.

Sare ireki hori osatuko lituzkeen kontzeptu, pertsona, memoria, idei edota objektuen erlazioen planteamendua, hala nola, Latour-ek soziologiaren esparrutik definitzen duen ANT (Action Network Theory) edo Aktore Sarearen Teoriatik abiatzen da; ikuspegi simetriko batetik, sarea eratzen duten agente aktiboen harremanen eraginen ondoriozko konfigurazioan datzan egitura. Laburki azalduta, etengabeko mugimendu eta desegonkortasunaren baitan eraldatzen diren agente hetereogenoen harremanak sarean egituratzen ditu Latour-ek, bertan suertatzen diren erlazionalitateen lotura eta talken ondorioz honakoa etengabe transformatuko delarik. Planteamendu honen baitan, kontzeptu anitzez osaturiko harreman eta gurutzadura aktiboen baitako analisi eta ezagutza-bide berriak proposatzen ditu teoria honen bitartez (Latour 2005). Adibide bisualtzat har ditzazkegu Gego artistaren Reticulárea (1969) obraren sare rizomatikoak espazioan duen hedapena, edota Tomas Saracenok 2009ko Veneziako Bienalean aurkeztutako Galaxies forming along filaments, like droplets along the strands of a spider's web instalazioa.
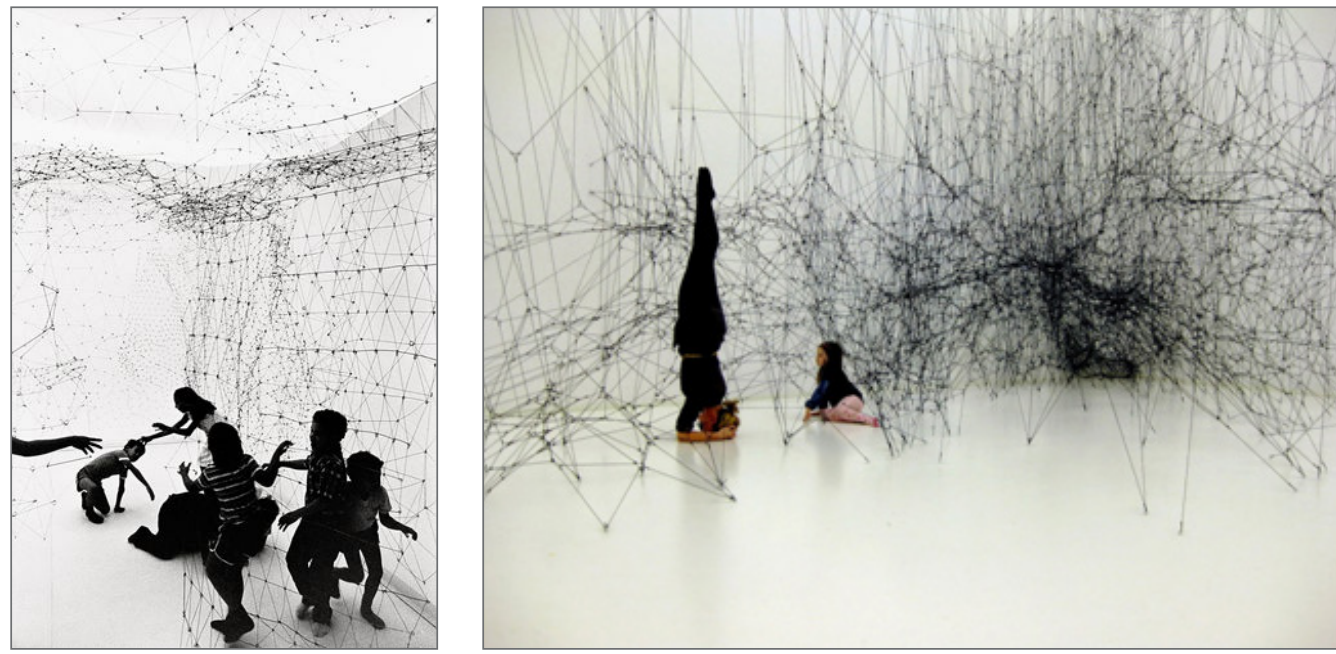

Gegoren "Reticulárea" (1969) obra, eta Saracenoren "Galaxies forming along filaments, like droplets along the strands of a spider's web" (2009) instalazioa.

Sarearen eta agente desberdinen harremanen bitartez ahalbidetuko litzateke, hain zuzen, gerturapen eta ezagutza prozesu honi loturiko disziplinartekotasuna. Sarearen mugimendu beraren arteko erlazionalitateak jarraituz antze- 
mango litzateke, presio, batuketa eta talken negoziazioen baitan, iraganaren eta orainaldiaren arteko artikulazioa eta, era berean, eraiketa edo berreraiketa prozesual posibleak.

Bestalde, jatorrizko linealtasunean ez bezela, planteamendu honek ohiko kronologiak alde batera uztea ahalbidetzen du, denboraren tolesduren arteko harreman bereziak posible eginez. Hala nola, iragan eta orainaldiaren arteko erlazioa sare hedatu moduan definitzerakoan, nolabait, denbora geruza desberdinen arteko multiplizitatea azaleratu egiten da. Bestalde, disziplinartekotasunetik gerturatzerakoan, eredu tenporal, objektual, espazial eta kontzeptualaren arteko paralelismoak sortuko lirateke, dena bihurtuz mugimendu, egitura eta desegituraketa beraren parte. Aukera aniztasun hau iraganaren gerturapen metodologiatzat hartzeak, oroimena garaikidetasunetik taxutzeaz gain, denbora gertakizunen pertzeptzio eta kontzeptualizazio interesgarrietara eraman gaitzake, arte esparrutik lantzerako askatasuna haintzat hartzen bada batez ere.

Sarearen eztabaida eta mugimenduz beteriko eztanda-puntu txikiak eutsi eta egituratzea litzateke, kasu honetan, artikulazioaren zeregina, perspektiba jakinetatik hausnartutako 'mikrokonstelazio' bat bailitzan. Iragana eta orainaldiaren arteko formalizazio horrek, hain zuzen, Kate King-ek proposatutako beste kontzeptu batera garamatza; 'berreraikuntza' edota 'arkeologi garaikide' deiturikora (King 2012, 139).

Hark definitutakoaren baitan, iraganarekiko edozein planteamendu orainalditik gauzatuko den arren, birsortzea lehenaldiakoaren kopian irudikatuko litzateke, errepikapen batean, nostalgiarekin bat egingo duen alegiazkotasunean. Artikulazioarekin bat dator, ordea, iraganarekiko lotura eta esperientzia horiek egituratzea, eta bir-transmititzea, berreraikitzea litzatekeena. Berreraikitzean, edo arkeologia garaikide deiturikoaren prozeduran, planteamendu honen bitartez defendatzen den moduan, iragana eraiketa berri batean gauzatuko da, baina egungo testuinguruaren eragin zuzen eta eraldatzailea izango duelarik bere hausnarketan.

“(...) recostruir una pieza no implica necesariamente una reposición del original. (...), este tipo de actitudes corren el riesgo de mitificar trabajos por el simple hecho de pertenecer a un pasado irrecuperable. Lejos de adoptar actitudes nostálgicas, las propues- 
tas más interesantes utilizan el pasado para reflexionar sobre el presente"

(Naverán 2010,12).

Birsortze eta berreraikitzearen talkan, bigarren honek ohiko planteamenduak zalantzan jartzen ditu, lehen aipaturiko desegonkortasun diakronikoarekin bat eginez. Aldaketa txiki horietan erreparatzeak, sarearen limite eta kontrasteen artean aurki daitezkeen zirrikitu eta bide alternatiboak jarraitu eta prozesuaren parte bihurtzea, denbora arteko lotura eta eraldaketa aktiboak gauzatuko ditu ezinbestean.

Diszplinarteko proposamen teoriko-metodologiko hau, ondaretze prozesuak garatzeko baliabidetzat proposatzen da arte garaikidearen esparrutik; dikotomien arteko eztandan, iragan eta orainaldiaren arteko elkarrizketaren bitartez ezagutza desberdin baten bidea emango da, instalazio performatibo eta hedatu moduan definituz 'patrimonializazioaren' (artikulazioaren) gakoa.

\section{ART(E/I)KULAZIO APLIKATUA. ARTE PRAKTIKA IRAGAN-ORAINALDIKO BERRERAIKUNTZA AKTIBOAN.}

Patrimonializaziotik artikulaziorantzko bideak, beraz, "obra" originalaren ideia baztertuko du, iraganarekiko ezagutza orainalditik eta era ireki, aktibo, hedatu eta performatibo baten moduan egituratuz, artikulazioaren ondorioa bihurtuko delarik ondare. Idei honek zuzeki egingo luke bat lehen aipaturiko patrimonializazio prozesu mardularen eta mugikortasun garaikidearen artean, ondarearen eta, bide batez, kultur-identitatearen eraikuntza prozeduren eta posmodernitatearen arteko sinergia berri bat eratuz. Planteamendu honekin bat, zera dio Martinez de Albeniz-ek, artearen bitartezko identitatearen eraikuntzaren inguruan:

"Se va dibujando (...) un desplazamiento que va de la obra aislada, expuesta en el altar del cubo blanco, a la instalación, pero no como mero estilema, como reflejo automático del campo expandido (...) (Krauss, 1979), sino como un síntoma cierto de la necesi- 
dad de abrir reflexivamente la obra a un terreno en el que sea cada vez más difícil ocultar su entramado."

(Martinez de Albeniz 2017, 18)

Azaldutako teoria metodologikoaren ideia ekarpen konkretuetara egokituz, Olga de Soto-ren proposamen artistikoa adibide garbia izan daiteke planteamendu guzti honi dagokionez ${ }^{2}$. Haren abiapuntua Jean Cocteau-ren El joven y la muerte dantza piezaren berreraiketaren saiakeran dago. Honakoa 1946. urtean Campos Eliseos antzokian estreinatu zen, Parisen (Naverán 2010, 125). Obraren grabaketa eta erregistrorik existitu ezean, ondare ez-material baten berreraiketaren saiakeran datza bere lana, obraren memoriaren berreskurapenean, eta berreaikipen eszenikoan. Konpainiako kide zirenen eta estreinuan egon zirenen ahozko erregistroak gauzatuz joan da urteetan zehar, iragan eta orainaldiaren arteko amildegira gerturatuz. Prozesuan zehar, oroimenaren parte diren esperientziak orainalditik artikulatzen ditu, egungoarekin performatuz, eta euren artean zein kontestu sozio-politiko eta historikoekin dituzten harremanak biziki azaleratuz, Historia(s) obraren bitartez formalizatuz (2004).

Garapenean zehar artikulatutakoaren mugimendua antzeman daiteke bere proposamenaren bitartez, baita iragan-orainaldiko saretik jarraitu dituen bideak, urteetan zehar sortu diren paralelismo, sentimendu, bategite eta eztanda aktiboak ere. Dokumentazioaren hausnarketa, eta jasotakoekin eratutako pieza, eraiketa berri baten parte da, obraren berreraiketa garaikidea.

Ondareak duen erregistro, dokumentu edo artxiboaren izaera estatikoa transzendituz, egungo kontestuan birrartikulatzen da obra hau, ikuslearen esperientziaren baitan berrirakurketa berriak eta ondare formula anitzak eratzeko aukera emanez. Berreraikitako obra beste hainbat esparrutan dantzatzerakoan ere eraldaketak sortzen dira, erlazio eta interpretazio berriak erakarriz, transmisioaren katea eta sarearen hedapen erlazionala geroz eta zabalagoa eginez, zentzu geruza berriak batuz. Gerora, prozesu antzekoa eraman du 1932an estreinatutako La mesa verde obraren berpiztearen bila.

Bi obra hauen berreraikuntzaren bitartez, de Sotok pieza beraren iragan, orainaldi eta etorkizunaren arteko mugak zalantza jartzen ditu, honakoaren partitura marko finkoetatik askatuz eta, ondorioz, begirada eta posizionamenduen arteko kontrastea sustatuz; galdera, elkarrizketa zein gorputz-mugimenduen berreraikuntzan eredu espazio-tenporal desberdinen arteko dialektika ostauz. Arte praktikaren eredu metodologikoak ematen dio, hain zuzen, ger- 
turapen horiekin jolasteko bidea, inmaterialtasunaren konstelazio-marko hori askatasunez eraiki eta lantzeko aukera sensiblea.

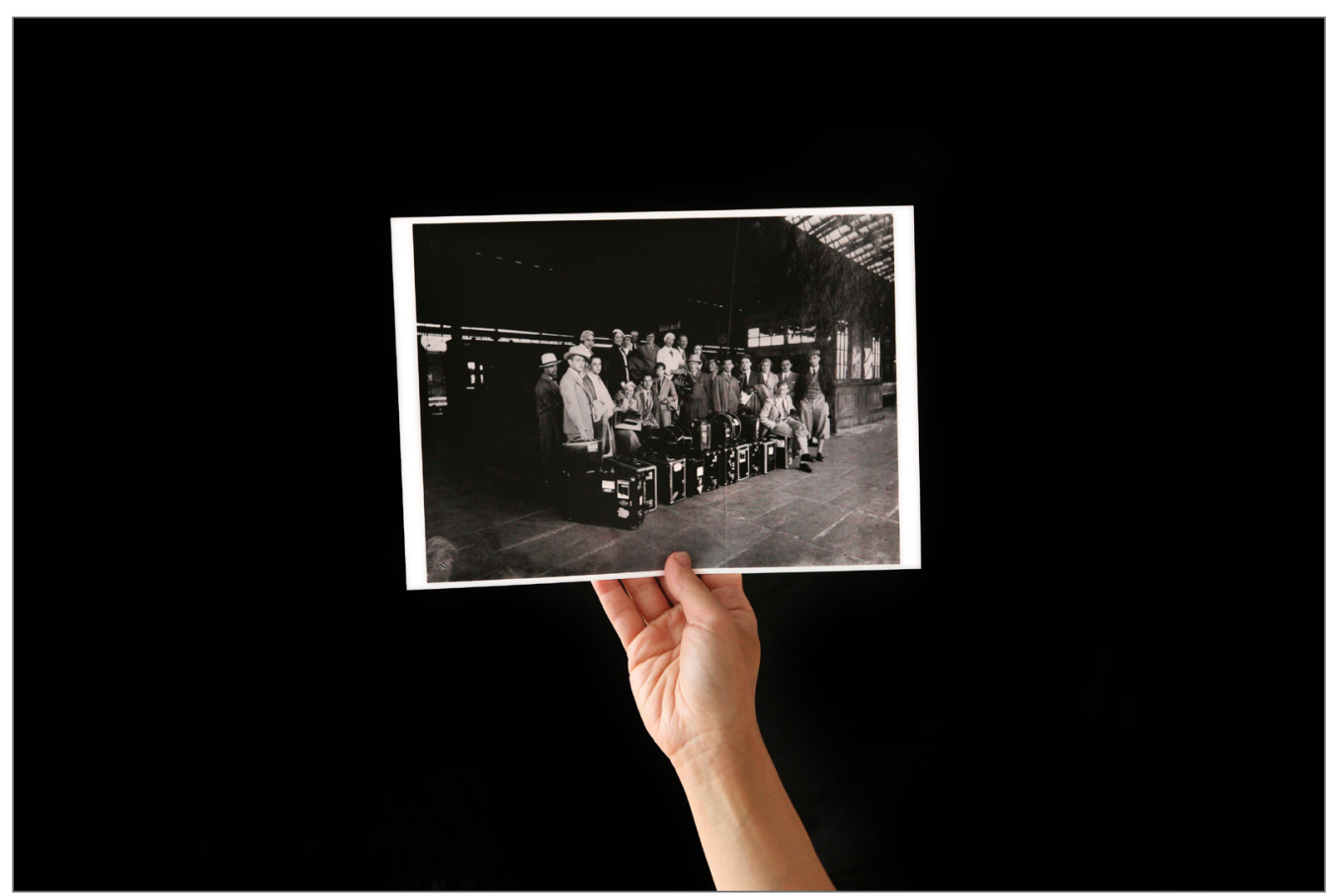

La Mesa Verde obraren iragarki-argazkia (2017).

Bigarren proposamen bat aipatzearren, Iratxe Jaio eta Klaas Van Gorkum-en lanek ere badute zerikusia iragan-orainaldiaren arteko elkarrizketa hortan. Naturaleza Muerta con Recipientes obran, adibidez, XX. mendeko lantegi industrial baten gerturapen arkeologikoa garatzen dute,ekintza garaikidetasunetik planteatuz betiere. Bertan ontzi anitzen molde zaharkituak aurkitu ondoren, honakoen berreraikipenera jotzen dute, harietatik pieza "berriak" eratzeko ideiaz. Iraganeko prozesua gaur egunean errepikatuz, nolabait, artxibo berri bat sortzen dute lantegiarekin bat egiten duten objektuekin, iraganeko aztarna eta zantzuen atzetik. Harietatik abiatuz, beraz, lantegi beraren radiografia modukoa eratzen dute, honakoa egungo kontestura erakarriz, iragan eta orainaldiaren arteko harreman berriak sortuz.

Erakusketari begira, ikerketa metodologiko hau instalazio batean egituratzen dute prozesuan zehar sortutako harreman eta erlazioak azaleratuz, oihartzun 
isilak artikulatuz, eta ikusgarri eginez. Ikuslearen esperientzia aktiboaren ondorioz, formalizatutako instalazioaren egitura gardena bihurtzen da, prozesuaren parte izan diren atalak ere obraren parte bihurtuz, eta kontestu anitzekin zuzenean bat egitea posible eginez (Bishop 2008, 52). Instalazioaren baitako formalizazioak, hain zuzen ere, guztiz bat egiten du eraiketa eta berreraiketa performatibo eta konstantearen ideiarekin, haren baitan ahalbidetzen baita ikusleak proposamenaren ideia bere kontura hausnartzea, identifikazioaren bitartezko harreman berriak eratuz, eratutako espazioan murgilduz, bere sarea fisikoki ere esperimentatuz. Edonola ere, iraganaren sare hedatura gerturatzeko eta artikulatzeko moduak posizionamenduaren baitakoak izango baitira beti, ikusteko moduaren araberakoak, euren hedapenean aktiboki eragiten dugun eraren baitakoak (Rubio eta Fogué 2017).
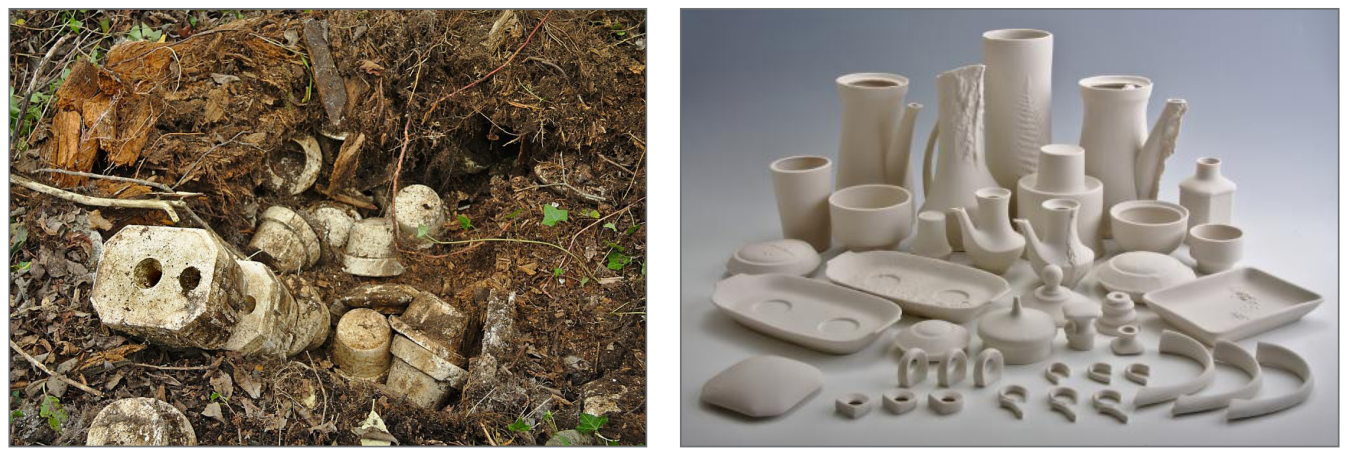

"Naturaleza muerta con recipientes" proposamenaren erregistroak,

"Agency of living organisms" erakusketako web orrialdetik ${ }^{3}$ (2016)

Ondoriozko narratiba eta ikusmira desberdinen bidean, Del Molinok eskuhartze horren alde egiten du zera dionean, norbera bere buruaren jabe izatea edo besteen menpe egotea bere kontakizuna sortu edo norbaitek harengatik sortzearen berdina dela (Del Molino 2016, 127). Eskumen hori haintzat hartzea ezinbestekoa izango da iragan eta orainaldiko elkarrizketa sustatzerako orduan, artikulazioaren baitan ondarea garaikidetasunetik lantzeko garaian, baliabide transbersal hauek ahalbidetuko baitute, hain zuzen ere, bere ondorio den kultur-identitatearen eraikuntza eta berreraikuntza prozesuaren parte aktibo eta performatibo izatea. 


\section{ONDORIOAK}

Egungo patrimonializazio prozesuek ondarea eredu itxi eta objektualen baitan lantzen dituztenez, kultur eta identitatearen mantenuaren erantzukizuna duten museoek eta patrimonializazio prozesuek, orokorrean, ondarearen ikuspegi mardula eskeini ohi dute, honakoak lehenaldian finkatuz, irudi esentzialisten baitan erreproduzituz iraganari loturiko ideiak. Proposamen hauek, hala nola, iraganarekin dugun harremanetan eragin zuzena dutela esan daiteke, egungo kultur-identitatearen eraikuntza eredu eta iruditegi konkretuetan mugatzen baitute. Mugikortasun eta informazioaren etengabeko hedapenaren garaian egon arren, beraz, iraganaren, ondarearen eta kultur identitatearen hausnarketa zentzu errepikakor eta esentzialisten baitan iristen dira gugana, kontestu posmodernoaren ezaugarrietara egokitzeko zailtasunez. Horrenbestez, gizartearen ondare eta kultur-identitatea iraganarekiko dugun gerturapen eta ezagutza motaz baldintzatuta egongo bada, ez da huskeria honakoarekin harremanetan egon nahi dugun moduen inguruan erreparatzea.

Iragana lantzeko eta ezagutzeko landu diren eta lantzen jarraitzen diren patrimonializazio prozesuak azaleratzeak, beraz, erreferente berrien beharra dakar, iraganaren lanketa estatiko edota performatiboaren arteko gatazkan. Hala nola, Said-en hitzen baitan aipatutako "esentzialismo sinkronikoa" eta harekin talka egiten duen diakronia (iraunkor eta iragankorraren arteko eztabaida) interesekotzat jotzen da estatizismo hori apurtzeko garaian, iragana orainalditik eta era aktibo batean ezagutzeko eta hausnartzeko alternatiben bila. Metodologia alternatibo eta transbertsalak aplikatzea ezinbestekoa izango da, beraz, etengabe aldatzen doazen iraganarekiko ezagutza eta harreman-loturak aktibo mantentzeko, orainalditik landu ahal izateko, eta ikusmira berriak erakarriko dituzten ikerketa-prozesuak garatzeko bidean.

Hala nola, patrimonializazio kontzeptutik artikulazioranzko jauzia proposatu da, iragana sare hedatu baten moduan planteatuz, Latour-en ANT teoria eta Krauss-en "hedatuaren" ideiei jarraiki; sarearen agente desberdinen arteko talka eta negoziazioak, eredu simetrikoa, dikotomien arteko eztandan sor daitezkeen bide berriak, denboraren multiplizitatea haintzat hartzea... baliabide bihurtzen dira iragana arte esparrutik lantzerako orduan, honakoaren artikulazioaren ondoriozko mugimenduan esku hartzeko, iragan-orainaldiko etengabeko elkarrizketaren eraiketa eta berreraiketa izango delarik haren gakoa. Patrimonializazio mardularen elementu fisiko baten mantenua, ondorioz, eraldaketa eta berreraikipen konstante baten isladan oinarritutako da, honakoa aldi baterako "iraunkorra" egitea, egituratu edo artikulatzea, orainaldira egokiturik 
emango delarik ezinbestean. Iraunkortasunaren esentzialismo sinkronikoa diakroniaren indarrekin eraldatuko da, euren arteko eztabaidan bide berriak sortuz, ikusmira berrietan murgiltzeko aukera emanez.

Proposamenak proposamen, arte esparruak iraganaren lanketa estatiko edo performatiboaren talkan eskumena duela antzeman daiteke aurkeztutako hausnarketa eta adibideen baitan, baita ondoriozko iruditegia lantzeko formula eta bide alternatiboetan parte hartzeko baliabideen eskaintza ere; euren artean dugu planteatutako sare hedatuaren artikulazioaren, performatibotasunaren, eta instalazioaren kontzeptuen artean dauden sinergiak, ereduen talka eta bategiteak. Honakoek ahalbidetuko dute, hain zuzen ere, mugimendu beran murgiltzea, gu eratzen gaituen etengabeko eraikuntza eta berreraikuntza prozesuren parte konszeinte eta aktibo izatea.

\section{Errefentziak}

Arrieta Urtizberea, Iñaki. 2015. Folclore y etnografía en los museos vascos: Una historia centenaria, una diacronía atemporal. Revista Andaluza De Antropología (9) 52-75. http://www. revistaandaluzadeantropologia.org/uploads/raa/n9/arrieta.pdf

Augé, Marc. 1998. Las formas del olvido. Itzulpena, Mercedes Tricás Preckler \& Gemma Andújar. Barcelona: Gedisa

Baena Díez, Francisco. 2004. "Donna Haraway: De la representación a la articulación”. Trama y Fondo 16:109-16

Barcenilla, Haizea. 2017. "Meatzaleak: Haizea Barcenilla". Youtubeko bideoa, 1:32:11. Zuzeneko emanaldia Azkuna Zentroan, ekainak 14. https://www.youtube.com/watch?v=s3DKGzV$\mathrm{dOxc} \& \mathrm{t}=2909 \mathrm{~s}$

Bauman, Zygmunt. 2002. La cultura como praxis. Itzulpena, Albert Roca Álvarez. Barcelona: Paidós

Bishop, Claire. 2008. "El arte de la instalación y su herencia”. Itzulpena, Jesús Carrillo. Ramona 78: $46-52$

Carbajo Padilla, Diego. 2010. "Entre ovejas, pastores y perros: Crónica de una intervención artística en clave ANT". Athenea Digital 19: 69-88

De Soto, Olga. 2017. "Olga de Soto". Bideoa, 20:27. Azala Tea-Tron, ekainak 28. http://www. tea-tron.com/azala/blog/2017/06/28/narrativas-56-olga-de-soto/

Del Molino Molina, Sergio. 2016. La España vacía: Viaje por un país que nunca fue. Madrid: Turner

Deleuze, Gilles.1990. “QQué es un dispositivo?”. En Michel Foucault filósofo, Etienne Balbier... et al.155-63. Barcelona: Gedisa

Díaz Balerdi, Iñaki. 2008. "Museos en la encrucijada: estructuras, redes y retos en el país vasco". En El futuro de los museos etnológicos: Consideraciones introductorias para un 
debate, XI Congreso de Antropología,Xavier Roigé, Esther Fernández \& Iñaki Arrieta, koord., 69-86. Donostia-San Sebastián: Ankulegi

Domínguez Rubio, Fernando \& Uriel Fogué Herreros. 2017. "Desplegando las capacidades políticas del diseño". Diseña 11: 96-109

García Selgas, Fernando José. 2007. Sobre la fluidez social: Elementos para una cartografía. Madrid: CIS

Gatti Casal de Rey, Gabriel \& Daniel Muriel Sánchez. 2001. "El patrimonio, en el quicio de lo viejo y lo nuevo". En La producción de la identidad en la sociedad del conocimiento: Cultura experta e identidad en el País Vasco, Gabriel Gatti \& Iñaki Martínez de Albeniz, ed., 25-67. Donostia-San Sebastián: Eusko Ikaskuntza

Halbwachs, Maurice. (1968) 2004. La memoria colectiva. Itzulpena, Inés Sancho-Arroyorena. Zaragoza: Universidad de Zaragoza

Haraway, Dona. 1991. Ciencia, "cyborgs" y mujeres: La reinvención de la naturaleza.Itzulpena, Manuel Talens. Madrid: Cátedra

Jaio, Iratxe \& Klaas Van Gorkum. 2016. "Naturaleza muerta con recipientes". Parallelports. org. Artículo sobre la instalación (exposicion 'The agency of living organisms', Tabakalera, 21/10/2016-5/2/2017)) http://parallelports.org/es/project/naturaleza-muerta-con-recipientes

King, Kate. 2011. Networked reenactments: Stories transdisciplinary knowledges tell.Durham, NC: Duke University

Krauss, Rosalind. (1979) 2002. “La escultura en el campo expandido”. En La posmodernidad, Jean Baudrillard et al.; Hal Foster, sel. \& hitzaurrea; itzulpena, Jordi Fibla, 59-74. BarceIona: Kairós

Latour, Bruno. (2005) 2008. Reensamblar lo social. Una introducción a la teoría actor-red. Itzulpena, Gabriel Zadunaisky.Buenos Aires: Manantial

Lowenthal, David. (1985) 2010. El pasado es un país extraño. Itzulpena, Pedro Piedras Monroy. Barcelona: Akal

Martínez de Albéniz Ezpeleta, Iñaki. 2017. “El arte como tecnología de la identidad: De la obra a la instalación”. Papeles del CEIC 1: 2-31. http://dx.doi.org/10.1387/pceic.16963

Naverán Urrutia, Isabel de, ed. 2010. Hacer historia: Reflexiones desde la práctica de la danza. Rabih Mroué et al. A Coruña: Centro Coreográfico Galego

Pazos Garciandía, Álvaro. 1998. "La re-presentación de la cultura: Museos etnográficos y antropología". Política y Sociedad 27: 33-45

Said, Edward W. (1997) 2008. Orientalismo. Itzulpena, Maria Luisa Fuentesena. Barcelona: DeBolsillo

Todorov, Tzvetan. 2000. Los abusos de la memoria. Itzulpena, Miguel Salazar. Barcelona: Paidós

Williams, Raimond. (1973) 2001. El campo y la ciudad. Itzulpena, Alcira Bixiorena. Buenos Aires: Paidós 


\title{
Oharrak
}

${ }^{1}$ Artikulu hau eta harekin erlazionaturiko hausnarketa Eusko Jaurlaritzako Doktoretza Aurreko laguntzarekin batera garatzen ari naizen Doktoretza Tesiaren parte da.

${ }^{2}$ Olga de Soto: Artiumen egindako elkarrizketa, 2017ko maiatzaren 12an. http://www.tea-tron. com/azala/blog/2017/06/28/narrativas-56-olga-de-soto/

${ }^{3}$ Agency of Living Organisms. https://agencyoflivingorganisms.com/es\#-3187,2066,0.5

\author{
(Artículo recibido 06-03-18; aceptado 23-04-18)
}

